\title{
Universal Basic Education in Nigeria: An Exploration of the Grounds of Misgivings
}

\author{
Joseph Izuchukwu Kanu and Chioma Uchenna
}

\author{
Abia State College of Education (Technical.)
} Arochukwu-Nigeria

Doi:10.5901/jesr.2013.v3n4p69

\begin{abstract}
The authors of this work inquire into the aberrations in the universal basic education (UBE) program in Nigeria with particular reference to the type of philosophy that underpin it. The outcome is that there is an over-whelming influence of pragmatism and empiricism in the UBE scheme; that pragmatism and empiricism were borrowed from British and American philosophy which do not really suit the Nigerian experience. The crux of the Nigerian problems is corruption which cannot be conquered through mere material change offered by the pragmatist and empiricist education. Spiritual and moral changes are necessary weapons against corruption. Consequently, the authors advocate that Nigerian education must transcend pragmatism and empiricism to idealism which emphasizes moral and spiritual development of learners.
\end{abstract}

\section{Introduction}

In every time and culture, education's aim is to foster moral/spiritual and physical or material aspects of the individual learner. In our own time therefore, and under the present demand for Universal Basic Education (UBE), we must seriously appraise the extent to which educational policy and scheme are achieving each of these aspects/needs of Nigerians. Certainly one observes an over-whelming influence of pragmatic philosophy and the different degrees of imports of idealism, realism and existentialism on the Nigerian national policy of education (Revise 2004).

It is therefore worthwhile for our education planners, stakeholder and in fact all concerned with determining the direction of our education to critically analyze how UBE has faired in the past fourteen years and under the so much talked about 9- 3- 4 educational system. This is to be done with the purpose of finding out its pit-falls, which must be avoided at the maturation and implementation levels of the 9-3-4 system of education. Since we belong to philosophy and philosophy of education departments, our contributions in this regard may not be more than a critical look at the philosophies that underpin the UBE and of course ascertaining their relevance or irrelevance to the Nigerian traditional values.

\section{The Nigerian Values}

Generally, values refer to the worth or essence of a thing. Value is that which accords usefulness or importance to something, persons or group of individuals. It is the reason for any admiration, satisfaction or sense of accomplishment inherent in man or any other thing.

Therefore a question on the Nigerian value is simply a question on what Nigeria is. The reason is that people are defined and identified by their autochthonous values without which their entire mode of being in the world remains not the same. Each generation and in fact successive government in Nigeria has had to grapple with the Nigerian cultural values in order to keep pace with the changing circumstance. But such changes and efforts must harmoniously mesh with the 
existing indigenous cultural values so as to preserve them and provide awareness for their growth and development. It is like Onwubiko (1991: x) wrote "education within the culture itself is a dual and sometimes simultaneous process of acculturation and enculturation."

With particular reference to Nigeria, we have to agree with Akinpelu (2001:10) that a wide range of virtues are derived from the Nigerian traditional moral values. These values he says are: "honesty, integrity, chastity, vivacity, modesty, tolerance, truthfulness, self-discipline and brotherliness, honor, humility, patience industry, self-control etc

It follows then that any meaningful step to fashion a common philosophy of education for the entire Nigeria must take serious cognizance of the Nigerian values, which when put together leaves a portrait of Nigeria. Okoh (2005) argues that if Nigeria is going to adopt an ideology, which is relevant to her people, such an ideology must be rooted in the essence of Nigeria. That is to say, it must be rooted in what makes Nigeria, Nigeria. This coheres with the thinking of Temples (1969) that although themes dealt within philosophy are universal, yet the treatment of any universal theme is relative to a people, coloured by their conception of life which every thing around them becomes meaningful.

\section{Education: a Tool for National Development?}

Nigerian's declaration that education is a tool for effective national development is worthy enough to create some dissenters among philosophers of education, educators and other scholars. Is education really a tool and what does it imply to reduce education to a tool? It might be argued on the positive dimension that viewing education as a tool for effective national development, as Nigeria does, is a worthwhile rationalization, that in whatever sense it is translated, one arrives at the perfection or attempt to perfect the society called Nigeria. Development in this manner of interpretation involves a gradual growth of all the integral parts especially the individuals that consist the nation. It might also be argued that effective development of individuals in the Nigerian context cuts-across the development of all aspects of man-physical/material, moral/spiritual and emotional/psychological. The makers of the Nigerian national policy on education will be okay with these contextual and conceptual explications even though they never thought along these lines when they defined education as a tool for effective national development.

Be that as it may, it must be admitted at least by philosophers of education and serious minded educators and scholars that the mere fact of referring education as a tool is a misnomer and a misconstruction of education. Education rather than being a tool is a process. The difference between a tool and a process in relation to education is very wide. A tool is simply a concrete instrument that can be manipulated by a master craftsman to achieve some desired practical ends. A process according to Wehmeier $(2000: 928)$ "is series of things that are done in order to achieve a particular result". Education is therefore not a tool because it involves series of activities to be carried out by teachers and students. Education's end is also not limited to practical results because it transcends the development of a physical man to the development of a moral-spiritual man. It is equally a contradiction to assume that education, wrongly interpreted as a material, concrete tool, can develop a spiritually/morally oriented man.

Here lies the LACUNA in the Nigerian education. Like a disease Nigerian's inability to understand what education really stands for has infected virtually all its educational programmes and activities. The reason for Nigerian's misconception of education is no other than its mad rush to imbibe British empiricism and American pragmatism. But what has actually happened to the Nigerian pupils and students with regard to the high trust Nigeria reposes on the over-dose of pragmatic and empiricist coloration of the Nigerian National policy on education exemplified in the present Universal Basic Education scheme? Is there no missing link amidst all these clamouring for practical, functional and mass education through the UBE? Okoh (2005:7) simply puts the question in this way; "what price must we (Nigerians) pay for the transformation of Nigeria into industrialized nation. Must we voraciously imbibe the tenets of materialism?" the danger we find 
ourselves by conceiving education as a tool is that of enthronement of matter and experiential elements and a crazy disapproval of metaphysical or ideal ingredients. Hence the dominant philosophical underpinnings of our education directly oppose man's cravings for transcendental succour. The outcome of this negation is as indicates by Kosemani (2000; xiii); "from what one sees and reads daily, one may conclude that morality has no place in our education system. This is reflected in our national life."

The UBE programme, with its promise of free education, more than ever, lures pupils and students (most of who are from poor parents) away from private and mission schools where according to Edet (1991-1992) moral instructions, the fear of God and the power of prayer are compulsory elements of the school curriculum. People like Obi C.A, Nwosu A.V., Eke C., Onwubiko KBC, Okon F.E., (1985) who had argued against secularization in the Nigerian education would see the UBE simply as Government's efforts to achieve perfect secularization of the Nigerian education; secularization understood in the sense of expunction of the idea of God and religion from education.

\section{UBE: Pragmatic and Existentialistic}

The Universal Basic Education (UBE) Scheme is predominantly of pragmatic and existentialistic orientations. Its prime pursuit is not merely to universalize education but to universalize functional, practical, relevant and appropriate education, the great desires of pragmatic and existentialistic education.

In the wake of all these clamours for practice, skill, industry, materiality, tangible productions from education, the danger of forgetting our moral and spiritual values looms high. Nwachukwu $(2005: 6)$ regrets that in the Nigerian education "values have become so perverted that the more important ones that account for a nations coherence have been relegated to the background." This risk of emphasizing praxis in education to the detriment of moral and spiritual elements must have informed Kosemani (2000) when he demanded that matters arising from the Nigerian education must essentially determine whether ideal values or pragmatic values are to be inculcated in the Nigerian child.

The UBE scheme applauds practical intellect far more than theoretical intellect, which works hand in hand with wisdom. Knowledge at the practical level means utilization or manipulation of instrument to one's service and to the service of the nation. Knowledge is not seen as the most vital action by means of which things are spiritualized in order to become integrated with the spirit, the real realm of the intellect and truth.

The intensity with which practical skill is emphasized in the UBE scheme seems to suggest that possession of knowledge is not actually what matters but that what matters is only the development of strength, skill, productivity in its concreteness and accuracy of mental powers. This we know belongs to the family of the sophists who were not out to teach the truth but to teach the art of speech and its practical effectiveness.

The Nigerian national policy on education (Revised 2004) Which is the anchorage for the Universal Basic Education (UBE) scheme is not silent about the kind of values which education should inculcate in the Nigerian children. The policy stipulates the following values:

1. Respect for the worth and dignity of the individual.

2. Faith in man's ability to make rational decisions etc.

One immediately sees the pragmatic and existentialistic tenets with their concomitantly individualistic tone on the Nigerian education.

\section{UBE: Individualism Against Altruism}

A philosophical insight into the provision of the Universal Basic Education (UBE) in Nigeria shows that its search light is on the individuality of the human person. Against this type of education 
Maritain in Kanu [2005] warned that education on the line of individuality will dislodge the human person and make him a slave of desire and passion. This also gives rise to the exhibition of the ego, which has the inclination to covet all for itself and disintegrate the personality. The quest for individuality goes concomitantly with the craze for external freedom, which perhaps the makers of the Nigerian policy on education (2004) borrowed from the pragmatists and the existentialists.

However, the primary aim of education is not so much the attainment of external freedom as it is the attainment of internal freedom. Internal freedom assures the individual autonomy, provides a response to the deepest yearning of the individual and it is not distracted from the unceasing development of intellect and will; it is rather committed to a progressive acquisition of intellectual and moral virtues. Consequently, education's primary aim is the conquest of spontaneity whose highest form is spiritual autonomy (Maritain J. in Operah 1985).

The second value (faith in man's ability to make rational decision) enuciatiated in the Nigerian national policy on education and to be pursued through the UBE scheme conveys much of individualism. It sounds like Sartre's (1905 1981) enthronement of individualism, which led him to atheism. The essence of man for Sartre lies in his profound aspiration to authenticate his individuality via a rational necessity, which is justifiable by man himself. This implies that man is the measure of all things, his own artifact and is absolutely free to cushion his destiny to any direction he chooses. With such total freedom accorded to man, the moral plane will be as Iroegbu (1995:255) puts it: "choose thyself, the content you This individualism inherent in the Nigerian national policy on education and which as a matter of fact has permeated the Universal Basic Education (UBE) can also lead to atheism, and be hazardous to moral sensitivity of our values. Biko (1978:42) expounded the same notion thus:

We (Africans) regard our living together Not as an unfortunate mishap warranting Endless competition among us but as a Deliberate act of God to make us a Community of brothers and sister jointly Involved in the quest for a composite Answer to the varied problems of life. All actions are usually joint community Oriented actions rather than the Individualism.

This implies that rather than being individualistic, the Nigerian education is to be as altruistic as the Nigerian autochthonous values are. Nwachukwu (2005:7) emphasizes the need for the Nigeria education to be altruistic when he wrote: "what is required is an educational context that prepares our citizen to recognize the necessity to be altruistic and to recognize that everyone can be better if they learn to function as a unit",

It is therefore clear that the needs and aspirations, the values, beliefs, norms and attitudes peculiar to Nigerians are not subsumable into the pragmatic or existentialist thesis on individuality. This is because like Mbiti (1975) noted for Africans/Nigerians, to be is to be religious in a religious world. Typically, African and indeed Nigerian indigenous education does not establish any demarcation between the sacred and the secular. The material and the spiritual are intricately interwoven in African cosmology. Religious belief therefore determine attitude to daily life and needs in the African/Nigerian authentic environment.

\section{UBE: Lack of Modus Operandi}

In fairness to the Nigerian national policy on education, we must admit that it has theoretically stipulated that: "moral and spiritual principles in interpersonal and human relations" ought to form part of the values to be inculcated in the Nigerian children in schools. But the difficulty here is that the UBE scheme, which is one of the avenues through which the said value is to be transmitted, lacks a distinct operational guideline for moral education. The Nigerian government merely asserts that ethical, moral and civil values shall be acquired through the UBE scheme without a clear cut 'Modus Operandi' for the acquisition of such values by pupils and students. 
This kind of ambiguity and ambivalence generate many philosophical questions viz: what is the source of moral and ethical values which the UBE strives to transmit? How should a Nigerian teacher teaching Nigerian children go about the teaching of Nigeria values? What kind of ethical values does the UBE proffer when it is dominantly influenced by pragmatic tenets? Where can the Nigerian traditional concept of God and his inseparable union with man be located in the UBE scheme? With the emphasis on civil values, are spiritual values of no importance to the UBE Scheme? How can a Nigerian child, through the UBE, be made to understand the Nigerian traditional concept of the world as a continuous flow of triadic forces, inanimate, animate and spiritual and given its individualistic posture, can the UBE ever transmit to the Nigerian children the Nigerian traditional idea of WE relationship?[Kanu 2007]

At the launching of the Universal Basic Education (UBE) scheme, the federal Government of Nigeria (1999:x) promised that the manner, contents and style of teaching various subjects in the Nigerian school are to be one of the areas of interest for the UBE scheme. Fourteen years have rolled by from the time of this important promise to the moment of this work, yet Nigerian schools have no clear-cut guideline for teaching moral education. Christian religious studies and Arabic or Islamic studies with their in-depth moral and spiritual formations are taught along academic lines and as means to academic success. Never are these subjects handled from their innate purpose of character formation. One may not be surprise at this great loophole or "sin of Omission" when one realizes that pragmatism and existentialism are the dominant philosophical underpinnings of the Nigerian education.

Thus the directionlessness of the Nigerian education is attributable to its over-sweeping inclination to pragmatism. This is because for the pragmatist values are relative, subjective, extrinsic and changeable. This implies that there is no universal moral standards, no absolute criteria for measuring the good life. Whatever that has no practical relevance is bad. The impact of this on the teachers and students in the classroom is as noted by Okoh (2005) that each has to determine for himself what the good life ought to be. The logical influences here are that if a student's behaviour aids him in achieving his practical desire, he is morally justified.

Teaching morality in schools presupposes that a specific standard be first prescribed as a model for all the teachers. But with the eclectic philosophical out look of the Nigerian national policy on education, it is not possible to initiate a general standard of morality in the Nigerian schools through the UBE scheme. The outcome of this is lack of spiritual or moral enrichment in the Nigerian curriculum of education. Okoh (2005:17) describes the situation thus: "our present eclectic philosophical posture can only bring about mere material change."

\section{Repositioning the Philosophical Base of the UBE (A Concluding Reflection)}

We have already mentioned elsewhere in this work that multifarious philosophies like idealism, realism (pragmatism and existentialism) informed and influenced the Nigerian education and that the same philosophies pervade the UBE programme. With this eclectic philosophy of education the makers of the Nigerian national policy on education strive to represent the Nigerian values. Since the Nigerian traditional concept of man is such that recognizes man as both a spiritual and a material being operating in a tripartite world, consisting of inanimate, animate and spiritual forces, the policy juxtaposes philosophical ideas, which are materialistic and idealistic.

However, the pre-eminence of pragmatism in the Nigerian education requires a re-visitation. Granted that in our epoch science and technology have become integral parts of a world culture, the enduring elements of a people's culture cannot be sacrificed on the altar of science and technology. The Nigerian education in keeping with the spirit of scientific innovations has made a swift departure from the theorizing, speculating and literary orientations of the old British 6-5-4system of education. But whether the new national policy on education exemplified in the UBE reformed agenda represents the Nigerian values is decipherable from the kinds of philosophies that underpin it. If its idealistic content blends harmoniously with its pragmatic posture and if its 
pragmatic colorations are curtailed by the fact that Nigerians are religiously and spiritually culture bound, then it goes far in reflecting the Nigerian values.

The reason for the above is simple- the idealistic character of the UBE should be able to retain the autochthonous Nigerian values whereas its pragmatic nature should align with the additive and substitutive qualities of cultural values. But if the Nigerian national policy on education and its UBE scheme emphasize pragmatism to the detriment of ideal values then there is a failure because man is not simple a "formless matter" and Nigerian values are not altogether changeable (Kanu 2007)

More over, the crux of the Nigerian problem may not be scientific and technological backwardness. The reason d'tre for Nigerian national policy on education (revised 2004) is that the old British 6-5-4- practiced in Nigeria failed to aid Nigerians in solving their problems. It follows logically that the new educational system must be able to find solutions to the Nigerian problems. Solution to a problem is known when the cause of the problem has been discovered. There can be many problems in Nigeria, but there must be one out of the many problems, which can be regarded as the bedrock or the primary cause of all the Nigerian problems.

If education, Nigerian education for that matter, is to be relevant to the problems of its people, then the Nigerian problems must be traced to its roots. That is to say the sources of the Nigerian problems must be identified and their taproot must be unearthed. Nigeria, since its inception has been in economic and socio-political hurdles. An endless litany of socio-political maladies bedeviling Nigeria; bribery and corruption, rapacious usury, drug trafficking, inflation of bills, injustices, inordinate quest for power leading to the reoccurrence of coup d'etat, armed robbery, deliberate assassination of human life, kidnapping, indiscipline, examination malpractice and extortion of the less privileged etc are all challenges to the Nigerian education.

These are great absurdities of our time, which subject most Nigerians to stinking economic and material poverty, to a life of perpetual drudgery, to social tension and personal disillusionment. The outcome of all these inhuman socio-economic conditions in Nigeria is manifesting in the youth restiveness from the oil producing area of the country, constant clamor and at times violent agitation for secession arising from a feeling of marginalization. Thus, the movement for Oduduwa Republic, Ogoni Kingdom, Sovereign state of Biafra and the ongoing pogrom from Boko Haram are all indications of disunity and disagreement with one indivisible and indissoluble Nigeria as professed in the overall Nigerian philosophy contained in the Nigerian national policy on education (Revise 2004).

The solution for all the above anomalies in Nigeria is not so much in scientific and technical education as it is in moral sanitization through rational moral education. For one thing, namely, absence of industrialization in Nigeria does not account for the amazing level of illiteracy and poverty among Nigerians, for another, that is, even if Nigeria outweighs America today in terms of science and technology, the social and economic conditions of its (Nigerian) populace may not differ from the present circumstance. The reason is that the inordinate and avaricious few in Nigeria will still covert public fund. Therefore, the core of the Nigerian problems, which faces the Nigerian education, is corruption. Education's contribution to war against corruption in Nigeria demands that the Nigerian philosophy of education should emphasize ideal values. Ideal values must therefore be given recognizable position in the Nigerian education. That is to say, idealism is to be the over whelming underpinnings of the Nigerian education and the UBE too, if at all education is to assist in solving a people's societal problems.

The 9-3-4- system of education in Nigeria must possess a distinct operational guideline for teaching moral education. This is because, the Nigerian education must first strive to develop the moral sense of its citizens so that the good fruits from science and technology and other mineral resources from the land can be utilized with the feeling and the interest of the other person in mind. Nigeria needs scientific innovations, Nigeria needs practical growth and development, Nigeria needs change. But the most important of the Nigerian needs is virtuousness to counter the wide range of viciousness in her education sector and in her larger society. 
Therefore Nigerian educational problems must transcend pragmatism. And beyond pragmatism lies idealism, the possible, remedy for Nigerian educational distempers.

\section{References}

Akinpelu J.A. Looking forward Nigerian education in the $21^{\text {st }}$ Century In Nigerian J ournal of Educational Philosophy (2001) 7 (1) Nigeria: philosophy of Education Association

Biko S. (1978) / write what / like. New York: John Willy Federal Republic of Nigeria (1999) Universal Basic Education for Nigeria. Zaria: Ahmadu Bello University Press.

Federal Republic of Nigeria (2004) National policy on Education. $4^{\text {th }}$ edition. Lagos: NERDC.

Federal Republic of Nigeria. Compulsory free Universal Basic Education Act 2004. Official Gazette Vol. 91-no.66. Lagos: The Federal Government press.

I roegbu, P. (1995) Metaphysics the KPIM of philosophy. Owerri: International University press.

Kanu J.I, (2005) A critical Analysis of the compulsory free Universal Basic Education Act 2004. In the African Journal of Education and Developmental studies (AJ EDES) Volume 1 and 2.

Kanu J.I. (2007) An inquiry into the philosophical Underpinning of the Nigerian education in the UBE Era An Unpublished M.Ed. Dissertation. University of Port Harcourt.

Kosomani, J.M. (2000), Nigerian Education: Matters Arising Port Harcourt: Abe publishers.

Mbiti, J.S. (1975), African Religions and philosophy London: Heinemann.

Nwachukwu, V.C. (2005) Issues of standard and sustainability of Quality Education A paper delivered at the seminar of the All- Nigerian conference of principals of secondary schools, Abia State chapter.

Obi C.A, Nwosu V.A, Eke C, Onwubiko KBC, and Okon .F E., (1985) A Hundred Years of the Catholic Church in Eastern Nigeria. 1885-1985. Onitsha: Africana-FEP Publishers.

Okoh, J.D. (2005) The risk of an Educational system without a Philosophical Base: Inaugural lecture series No 38. University Of Port Harcourt: UPPL press.

Onwubiko, O.A. (1991) African thought, religion and culture. Enugu: SNAAP press.

Opera, D.A. (1985) The Humanistic Aim of Education in Jacques Maritain. U.S.A: McGraw-Hill Book.

Temple P. (1969) Bantu philosophy. Paris: presence Africana

Wehmeier.S. (2000) Oxford Advance Learner's Dictionary $6^{\text {th }}$ Edition Oxford University press. 
